\title{
New Austalides from the Sponge-Associated Fungus Aspergillus sp.
}

Yaming Zhou, ${ }^{[\mathrm{a}]}$ Attila Mándi, ${ }^{[\mathrm{b}]}$ Abdessamad Debbab, ${ }^{[\mathrm{a}]}$ Victor Wray, ${ }^{[\mathrm{c}]}$ Barbara Schulz, ${ }^{[\mathrm{d}]}$ Werner E. G. Müller, ${ }^{[\mathrm{e}]}$ WenHan Lin, ${ }^{[\mathrm{f}]}$ Peter Proksch, ${ }^{[\mathrm{a}]}$ Tibor Kurtán, ${ }^{[\mathrm{b}]}$ Amal H. Aly*[a]

[a] Institut für Pharmazeutische Biologie und Biotechnologie, Heinrich-Heine-Universität, Universitätsstrasse 1, Geb. 26.23, D-40225 Düsseldorf, Germany Fax: +49 21181 11923, E-mail: amal.hassan@uni-duesseldorf.de

[b] Department of Organic Chemistry, University of Debrecen, POB 20, 4010 Debrecen, Hungary Fax: +36 52453 836, E-mail: kurtan.tibor@science.unideb.hu

[c] Helmholtz Centre for Infection Research, Inhoffenstraße 7, D-38124 Braunschweig, Germany

[d] Institut für Mikrobiologie, Technische Universität Braunschweig, Spielmannstraße 7, 31806 Braunschweig, Germany

[e] Institut für Physiologische Chemie und Pathobiochemie, Johannes-Gutenberg-Universität, Duesbergweg 6, D-55128 Mainz, Germany

[f] National Research Laboratories of Natural and Biomimetic Drugs, Peking University, Health Science Center, 100083 Beijing, People's Republic of China

\begin{abstract}
Chromatographic separation of a crude extract obtained from the fungus Aspergillus sp., isolated from the Mediterranean sponge Tethya aurantium, yielded five new meroterpenoid metabolites, austalides M-Q (1-5), together with nine known compounds (6-13). The structures of the new compounds were unambiguously elucidated on the basis of extensive 1D and 2D NMR methods and mass spectral analysis. Furthermore, the absolute configurations of $\mathbf{1}$ and $\mathbf{4}$ were determined by TDDFT ECD calculations allowing the assignment of derivatives $\mathbf{2 ,} \mathbf{3}$ and $\mathbf{5}$ as well. The calculations revealed that the conformation of the benzene-fused phtalide chromophore, sensitive to even minor changes in its proximity, is decisive for the ECD parameters rendering the simple ECD comparison of related homochiral austalides difficult. All compounds were evaluated for their cytotoxic activity against murine cancer cell line L5178Y by the MTT method. Compounds $\mathbf{8}$ and $\mathbf{1 1}$ exhibited
\end{abstract}


moderate to pronounced cytotoxicity with $\mathrm{IC}_{50}$ values of 39.4 and $0.2 \mu \mathrm{M}$, respectively, whereas the remaining investigated compounds showed weak or no activity in this assay.

\section{Keywords}

Sponge-associated fungi; marine natural products; Aspergillus; Tethya aurantium; cytotoxicity; TDDFT ECD calculation; chroman chromophore

\section{Introduction}

Over the past years, marine microorganisms have proven to be a prolific source of structurally interesting and biologically active natural products. Marine fungi in particular have attracted considerable interest due to the diversity in chemical structures and biological activities observed for their secondary metabolites. ${ }^{[1,2]}$ Bioactive natural products from marine-derived fungi were reported for the first time back in the 1940s from a fungal strain of Acremonium chrysogenum, which yielded cephalosporin $\mathrm{C}$, the parent compound of cephalosporin antibiotics. ${ }^{[3]}$ Meanwhile, marine-derived fungi have been isolated from various organisms, including algae, mollusks and particularly sponges. ${ }^{[4,5]}$ Yet, sponge-derived fungi were found to be among the most prolific sources of bioactive compounds. ${ }^{[6]}$

The genus Aspergillus (Moniliaceae) contains approximately 180 species found in various climates worldwide in both terrestrial and marine environments. ${ }^{[7]}$ Aspergillus species and their chemical profiles have been studied by numerous research groups. The genus has proven to be a rich source of secondary metabolites with novel structures and interesting bioactivity. ${ }^{[8-12]}$ Examples of isolated metabolites include meroterpenoids, ${ }^{[11,13-15]}$ isochroman derivatives,${ }^{[10,16-18]}$ drimane sesquiterpenoids, ${ }^{[8,19]}$ and cyclic tripeptides, ${ }^{[12]}$ which exhibited interesting biological activities, such as plant growth inhibition, ${ }^{[16]}$ cytotoxic activity against tumor cell lines, ${ }^{[8,10]}$ selective 
antifungal activity, ${ }^{[12]}$ as well as inhibition of endothelin-type B receptors. ${ }^{[19]}$

As part of our ongoing research on marine fungi, ${ }^{[8,20,21]}$ we have investigated a marine-derived fungal Aspergillus strain, isolated from a specimen of the Mediterranean sponge Tethya aurantium. In this study five new meroterpenoids, named austalides M-Q (1-5) (Figure 1), along with nine known compounds (6-13), were isolated. Previously known compounds were identified by comparing their spectroscopic and physical data $\left({ }^{1} \mathrm{H}\right.$ and ${ }^{13} \mathrm{C}$ NMR, MS and $\left.[\alpha]_{\mathrm{D}}\right)$ with literature values. The structure elucidation of the new metabolites, austalides M-Q (1-5), is described in detail. Moreover, all compounds isolated were evaluated for their cytotoxicity against the murine lymphoma cell line L5178Y using the MTT assay.

\section{Results and Discussion}

The mycelia and culture medium of the fungus Aspergillus sp. were extracted with ethyl acetate. The resulting crude ethyl acetate extract was subjected to repeated column chromatography followed by semi-preparative HPLC separation to obtain five new austalides M-Q (1-5) (Figure 1), along with eight known compounds (6-13). Based on the spectroscopic data and comparison with data reported in the literature, the known compounds 6-13 (Figure 2) were readily identified as 4-acetyl-3,4-dihydro-6,8-dihydroxy-3-methoxy-5-methylisocoumarine (6), ${ }^{[22]} 2,3,4$ trimethyl-5,7-dihydroxy-2,3-dihydrobenzofuran (7), ${ }^{[23]}$ 4-acetyl-3,4-dihydro-6,8dihydroxy-5-methylisocoumarine (8), ${ }^{[24]}$ phenol A acid $(\mathbf{9}),{ }^{[25]}$ butyrolactone II (10), ${ }^{[26,27]}$ methyl-3,4,5-trimethoxy-2-(2-(nicotinamido)benzamido)benzoate $(\mathbf{1 1}),{ }^{[28]}$ citrinin (12), ${ }^{[29]}$ and dicitrinin A (13). ${ }^{[30,31]}$ Compound 11, previously isolated from Aspergillus fumigatus collected from the air and dust of asthmatic patients' rooms, ${ }^{[32]}$ is reported here for the first time from a sponge associated fungus. The new metabolites (1-5) were found to be structurally related to the known austalides A-L previously isolated from Aspergillus ustus. ${ }^{[13,14]}$ 
The molecular formula of $\mathbf{1}$ was established as $\mathrm{C}_{27} \mathrm{H}_{36} \mathrm{O}_{9}$ on the basis of the $[\mathrm{M}+\mathrm{H}]^{+}$signal at $m / z 505.2423$ in the HRESIMS. Its UV spectrum showed maxima at $\lambda_{\max } 223$ and $267 \mathrm{~nm}$ characteristic of a substituted phthalide moiety. ${ }^{[14]}{ }^{1} \mathrm{H}$ and ${ }^{13} \mathrm{C}$ NMR spectra (Tables 1 and 3) indicated the presence of eight methyl groups appearing as singlets in the ${ }^{1} \mathrm{H}$ NMR spectrum, including three methoxy groups resonating at $\delta_{\mathrm{H}} 3.40,3.50$ and $4.13 \mathrm{ppm}\left(\mathrm{CH}_{3}-28,-31\right.$ and -29 , respectively), one aromatic methyl group at $\delta_{\mathrm{H}} 2.08 \mathrm{ppm}\left(\mathrm{CH}_{3}-23\right)$, and four aliphatic methyl groups at $\delta_{\mathrm{H}} 0.90,1.33,1.48$ and $1.60 \mathrm{ppm}\left(\mathrm{CH}_{3}-27,-24,-26\right.$ and -25 , respectively). In addition, four methylene groups were observed, one of which was attributed to the oxygenated benzylic methylene group at $\mathrm{C}-1\left(\delta_{\mathrm{H}} 5.23 \mathrm{ppm}, \mathrm{s}\right)$, as well as three methine groups, two of which are situated on oxygen-bearing carbon atoms as indicated by their chemical shift values at $\delta_{\mathrm{H}} 4.11$ and $4.44 \mathrm{ppm}$ (H-13 and $\mathrm{H}-22$, respectively). The ${ }^{13} \mathrm{C}$ NMR spectrum (Table 3) confirmed the presence of 27 carbon atoms in the structure. Furthermore, the DEPT experiment revealed the presence of 12 quaternary carbon atoms. Analysis of the ${ }^{1} \mathrm{H}-{ }^{1} \mathrm{H}$ COSY spectrum of $\mathbf{1}$ (Table 1, Figure 3) established the presence of three spin systems which included the correlations observed for the methylene protons resonating at $\delta_{\mathrm{H}} 2.19$ and $2.32 \mathrm{ppm}\left(\mathrm{CH}_{2}-12\right)$ to the deshielded methine group at $\mathrm{C}-13$, and for the methine proton appearing at $\delta_{\mathrm{H}} 2.50 \mathrm{ppm}(\mathrm{H}-21)$ to the deshielded methine group at C-22. Moreover, the correlation between the protons of both methylene groups at C-18 and C-19 verified the third spin system. Interpretation of the HMQC spectrum allowed the assignment of proton signals to the corresponding proton-bearing carbon atoms.

The connection between the different substructures of $\mathbf{1}$ was determined by inspection of the HMBC spectrum (Table 1, Figure 3). The tertiary methyl group $\mathrm{CH}_{3}-27\left(\delta_{\mathrm{C}} 19.2\right)$ correlated with the quaternary carbon $\mathrm{C}-20\left(\delta_{\mathrm{C}} 39.8\right), \mathrm{CH}_{2}-19\left(\delta_{\mathrm{C}}\right.$ 31.4), $\mathrm{CH}-21$ ( $\left.\delta_{\mathrm{C}} 43.6\right)$, and an oxygenated quaternary carbon resonating at $\delta_{\mathrm{C}} 87.7$ assigned to C-14. C-14 further correlated with the methyl groups $\mathrm{CH}_{3}-25$ and $\mathrm{CH}_{3}-26$ 
( $\delta_{\mathrm{C}} 26.5$ and 29.2, respectively), which were found to constitute a geminal dimethyl moiety, as indicated by their correlation with each other as well as with an oxygenated quaternary carbon resonating at $\delta_{\mathrm{C}} 86.1(\mathrm{C}-15)$. Furthermore, the methoxy group $\mathrm{OCH}_{3}-28\left(\delta_{\mathrm{C}} 49.0\right)$ correlated with a highly deshielded quaternary carbon resonating at $\delta_{\mathrm{C}} 120.3$ which was assigned to $\mathrm{C}-17$, in agreement with reported chemical shifts observed for the carbon atom of ortho esters. ${ }^{[14]} \mathrm{H}-21$ correlated with C-20, C-22, $\mathrm{CH}_{3}-27$, and an aromatic quaternary carbon at $\delta_{\mathrm{C}} 119.4$ (C-6). The location of $\mathrm{OCH}_{3}-31\left(\delta_{\mathrm{C}} 56.4\right)$ was established based on its correlation with C-22. H-22 correlated with C-20, C-31, C-6, as well as with three oxygenated quaternary carbons, two aromatic ones overlapping at $\delta_{\mathrm{C}} 158.9$, and an aliphatic one at $\delta_{\mathrm{C}} 77.3$, assigned to $\mathrm{C}-5, \mathrm{C}-7$ and $\mathrm{C}-11$, respectively. Correlations of the tertiary methyl group $\mathrm{CH}_{3}-24$ $\left(\delta_{\mathrm{C}} 28.8\right)$ with $\mathrm{C}-11, \mathrm{C}-21$ and $\mathrm{CH}_{2}-12\left(\delta_{\mathrm{C}} 43.8\right)$ provided the remaining connections of the spin systems previously observed in the ${ }^{1} \mathrm{H}-{ }^{1} \mathrm{H}$ COSY spectrum. The methoxy group $\mathrm{OCH}_{3}-29\left(\delta_{\mathrm{C}} 63.3\right)$ was attached to $\mathrm{C}-5$ as indicated by the respective HMBC correlation. The aromatic $\mathrm{CH}_{3}-23\left(\delta_{\mathrm{C}} 10.7\right)$ correlated to the quaternary aromatic carbons C-7, C-8 $\left(\delta_{\mathrm{C}} 116.2\right)$, and C-9 $\left(\delta_{\mathrm{C}} 149.3\right)$, and hence was placed at C-8. The remaining ${ }^{13} \mathrm{C}$ resonances at $\delta_{\mathrm{C}} 108.9$ and 171.5 were attributed to the remaining $s p^{2}$ carbon atom of the completely substituted benzene ring (C-4) and the carbonyl carbon C-3, respectively. This was further confirmed by correlation of C-9 with the oxygenated benzylic methylene group $\mathrm{CH}_{2}-1\left(\delta_{\mathrm{C}} 70.0\right)$, which in turn correlated with C-4 and C-3.

The relative configuration of $\mathbf{1}$ was deduced from analysis of the ROESY spectrum. Correlations were observed for $\mathrm{CH}_{3}-24$ to $\mathrm{H}-21$ indicating that rings $\mathrm{C}$ and $\mathrm{D}$ are $c i s$-fused. This was further confirmed by $\mathrm{OCH}_{3}-31$ correlations to $\mathrm{H}-21$ and $\mathrm{CH}_{3}-24$. The correlation observed between $\mathrm{CH}_{3}-27$ and $\mathrm{H}-22$, but not to $\mathrm{H}-21$, indicated a trans relationship between $\mathrm{CH}_{3}-24$ and $\mathrm{CH}_{3}-27$. $\mathrm{CH}_{3}-25$ and $\mathrm{CH}_{3}-27$ as well as $\mathrm{CH}_{3}-26$ and $\mathrm{H}-13$ are cis oriented based on the correlations observed between 
them. Consequently, ring $\mathrm{C}$ is cis-fused with ring B and trans-fused with the seven-membered ring. Thus, the relative stereochemistry of $\mathbf{1}$ was established as $\left(11 S^{*}, 13 R^{*}, 14 R^{*}, 20 R^{*}, 21 S^{*}, 22 S^{*}\right)$. For the determination of the absolute configuration, the solution ECD spectrum of $\mathbf{1}$ was recorded in acetonitrile and TDDFT ECD calculation of solution conformers was carried out. The experimental ECD spectrum is dominated by the strong negative Cotton effect (CE) at $217 \mathrm{~nm}(\Delta \varepsilon=$ 16.00) accompanied by a positive $\mathrm{CE}$ at $196 \mathrm{~nm}(\Delta \varepsilon=5.61)$ and three weaker transitions at 262, 295 and $301 \mathrm{~nm}$ (Figure 4). The MMFF conformational search followed by B3LYP/6-31G(d) DFT reoptimization afforded two conformational isomers (conformer A and B in Figure 5 with $77.2 \%$ and $19.5 \%$ populations) above $3 \%$ population. The two conformers showed minor differences in the orientations of methoxy and hydroxy groups and the conformation of the fused phtalide moiety. In both conformers, the benzylic 22-OMe group adopted axial orientation to relieve the peri interaction with the 5-OMe group and the pyran ring of the chroman chromophore had $M$ helicity. The weak coupling between H-22 and the contiguous $\mathrm{H}-21$, indicating a torsion angle close to $90^{\circ}$ between these vicinal protons, ${ }^{[33]}$ corroborated the axial orientation of the 22-OMe group. In spite of their similarities, the computed ECD spectra of the two conformers were significantly different (Figure SI1 and SI2), i.e. the major conformer reproduced well the two intense high-energy CEs, while the minor one seems responsible for the negative CE at $262 \mathrm{~nm}$. The different ECDs of the conformers were attributed to the different orientation of the C-3 carbonyl relatively to the benzene ring $\left(\omega_{\mathrm{O} 3, \mathrm{C} 3, \mathrm{C} 4, \mathrm{C} 9}\right)$. The torsional angle $\omega_{\mathrm{O} 3, \mathrm{C} 3, \mathrm{C} 4, \mathrm{C} 9}$ Was found to be $-178.8^{\circ}$ for the major conformer and $+174.3^{\circ}$ for the minor one. The Boltzmann-weighted ECD spectra of the two conformers reproduced well the two strong CEs of the high-energy region, which allowed determining the absolute configuration of $\mathbf{1}$ as (-)-(11S,13R,14R,20R,21S,22S). However, the agreement was quite poor for the weak transitions above $250 \mathrm{~nm}$, which could be 
improved by setting the ratio of the two conformers to 1:1 (see Figure SI3). The CD calculation revealed that the $\omega_{\mathrm{O} 3, \mathrm{C} 3, \mathrm{C} 4, \mathrm{C} 9}$ torsional angle and ratio of the conformers, determined by the central chirality elements, are decisive for the observed CEs, which makes the application of the chroman helicity rule ${ }^{[34]}$ unrelevant.

The absolute configuration of $\mathbf{1}$ corraborates those determined for austalides A and D by X-ray crystallographic studies. ${ }^{[15,35]}$ However, austalide D has an additional chirality center due to an additional C-19 acetoxy group, and the C-22 chirality center of $\mathbf{1}$ is missing from both austalides A and D due to the lack of the 22-methoxy substituent. ${ }^{[15,35]}$ Thus, $\mathbf{1}$ was identified as a new natural product and named as austalide M.

Compound $\mathbf{2}$ displayed similar spectral data to those of $\mathbf{1}$ suggesting that both compounds have the same basic molecular framework. HRESIMS indicated the molecular formula $\mathrm{C}_{28} \mathrm{H}_{36} \mathrm{O}_{10}$ in accordance with the $[\mathrm{M}+\mathrm{H}]^{+}$signal at $m / z$ 533.2388, thus revealing a 28 amu increase in the molecular weight compared to $1 .{ }^{1} \mathrm{H},{ }^{13} \mathrm{C}$ NMR and DEPT spectra of $\mathbf{2}$ were similar to those of $\mathbf{1}$ (Tables 1 and 3) except for the replacement of the benzylic C-22 methoxy group by a methyl ester group resonating at $\delta_{\mathrm{H}} 2.07$ and $\delta_{\mathrm{C}} 21.3\left(\mathrm{CH}_{3}-32\right)$. The respective ester carbonyl carbon was detected at $\delta_{\mathrm{C}} 171.6(\mathrm{C}-31)$. This was further confirmed by the observed downfield chemical shift of the H-22 signal ( $\left.\delta_{\mathrm{H}} 6.21\right)$ caused by the acetyl substituent. Inspection of COSY, HMQC and HMBC spectra (Table 1) indicated that apart from the methyl ester function at C-22, the two compounds were identical. Based on the ROESY spectrum, 2 has $\left(11 S^{*}, 13 R^{*}, 14 R^{*}, 20 R^{*}, 21 S^{*}, 22 S^{*}\right)$ relative configuration in accordance with the corresponding chirality centers of $\mathbf{1}$. Accordingly, $\mathbf{2}$ was finally characterized as a new natural product named austalide $\mathrm{N}$.

The molecular formula of 3 was determined as $\mathrm{C}_{26} \mathrm{H}_{34} \mathrm{O}_{9}$, from the prominent signal at $m / z 491.2293$ corresponding to $[\mathrm{M}+\mathrm{H}]^{+}$in the HRESIMS, indicating a loss of 14 amu compared to $\mathbf{1}$. Physicochemical data of $\mathbf{3}$ were almost identical with those 
of 1 (Tables 1 and 3) apart from the disappearance of the C-22 methoxy group in the NMR spectra of $\mathbf{3}$. This suggested that $\mathbf{3}$ possesses the same skeleton as $\mathbf{1}$ but it has a benzylic 22-OH group instead of the 22-OMe, which accounts for the $14 \mathrm{amu}$ molecular weight difference. Accordingly, slight downfield and large upfield shifts were observed for $\mathrm{H}-22\left(\delta_{\mathrm{H}} 4.97\right)$ and $\mathrm{C}-22\left(\delta_{\mathrm{C}} 62.0\right)$, respectively, in the ${ }^{1} \mathrm{H}$ and ${ }^{13} \mathrm{C}$ NMR spectra of $\mathbf{3}$. As with $\mathbf{2}$, further confirmation of the planar structure was achieved by analysis of DEPT, COSY, HMQC and HMBC spectra (Table 1). Moreover, the ROESY spectrum indicated the $\left(11 S^{*}, 13 R^{*}, 14 R^{*}, 20 R^{*}, 21 S^{*}, 22 S^{*}\right)$ relative configuration in agreement with those of $\mathbf{1}$ and $\mathbf{2}$. Hence, $\mathbf{3}$ was identified as a new natural product and named austalide $\mathrm{O}$.

Compound 4 has the molecular formula of $\mathrm{C}_{26} \mathrm{H}_{36} \mathrm{O}_{7}$, from the HRESIMS with a prominent peak at $m / z 483.2349[\mathrm{M}+\mathrm{Na}]^{+}$. Its physical characteristics were also comparable to those of $\mathbf{1}$ suggesting the same basic molecular framework. ${ }^{1} \mathrm{H}$ and ${ }^{13} \mathrm{C}$ NMR spectra of 4 (Tables 2 and 3) indicate the presence of seven methyl groups appearing as singlets in the ${ }^{1} \mathrm{H}$ NMR spectrum, including two methoxy groups resonating at $\delta_{\mathrm{H}} 3.68$ and $4.04 \mathrm{ppm}\left(\mathrm{CH}_{3}-28\right.$ and -29 , respectively), one aromatic methyl group at $\delta_{\mathrm{H}} 2.08 \mathrm{ppm}\left(\mathrm{CH}_{3}-23\right)$, and four aliphatic methyl groups at $\delta_{\mathrm{H}} 0.70$, 1.20, 1.19 and $1.27 \mathrm{ppm}\left(\mathrm{CH}_{3}-27,-24,-25\right.$ and -26 , respectively). In addition, six methylene groups were observed, one of which was attributed to the oxygenated benzylic methylene group at $\mathrm{C}-1\left(\delta_{\mathrm{H}} 5.21 \mathrm{ppm}, \mathrm{s}\right)$, as well as two methine groups. The ${ }^{13} \mathrm{C}$ NMR spectrum (Table 3) confirmed the presence of 26 carbon atoms in the structure. Furthermore, the DEPT experiment revealed the presence of 11 quaternary carbon atoms. Analysis of the ${ }^{1} \mathrm{H}-{ }^{1} \mathrm{H}$ COSY spectrum of 4 (Table 2, Figure 6) established the presence of three spin systems which included the fragment $\mathrm{CH}_{2}(12) \mathrm{CH}_{2}(13) \mathrm{CH}(14)$ based on the correlations observed between the corresponding protons resonating at $\delta_{\mathrm{H}} 1.61\left(\mathrm{CH}_{2}-12\right), 1.52$ and $1.83\left(\mathrm{CH}_{2}-13\right)$, as well as $2.14(\mathrm{H}-14) \mathrm{ppm}$, thus indicating the loss of the hydroxyl group substituent at 
C-13 present in 1-3 as well as of the oxo-bridge connecting C-14 to C-17. Moreover, the correlation between the protons of methylene groups at C-18 $\left(\delta_{\mathrm{H}} 2.32\right.$ and 2.60 ppm) and $\mathrm{C}-19\left(\delta_{\mathrm{H}} 1.80\right.$ and $\left.2.42 \mathrm{ppm}\right)$, and between the methylene protons appearing at $\delta_{\mathrm{H}} 2.78$ and $3.03 \mathrm{ppm}\left(\mathrm{CH}_{2}-22\right)$ to the methine group at $\mathrm{C}-21\left(\delta_{\mathrm{H}} 1.70 \mathrm{ppm}\right)$ verified the remaining two spin systems. Proton signals were assigned to their corresponding carbon atoms by analysis of the HMQC spectrum.

The structural units identified in $\mathbf{4}$ were connected on the basis of correlations observed in the HMBC spectrum (Table 2, Figure 6). The tertiary methyl group $\mathrm{CH}_{3}-27\left(\delta_{\mathrm{C}} 19.5\right)$ correlated with the quaternary carbon C-20 $\left(\delta_{\mathrm{C}} 41.6\right), \mathrm{CH}_{2}-19\left(\delta_{\mathrm{C}}\right.$ 34.9), $\mathrm{CH}-21\left(\delta_{\mathrm{C}} 41.2\right)$, and $\mathrm{CH}-14\left(\delta_{\mathrm{C}} 40.1\right)$. C-14 further correlated with the methyl groups $\mathrm{CH}_{3}-25$ and $\mathrm{CH}_{3}-26$ ( $\delta_{\mathrm{C}} 28.0$ and 33.2, respectively), which were found to constitute a geminal dimethyl moiety, as indicated by their correlation with each other as well as with an oxygenated quaternary carbon resonating at $\delta_{\mathrm{C}} 75.7(\mathrm{C}-15)$. The upfield chemical shift of C-15 in $\mathbf{4}$ compared to that observed in 1-3 indicated its location within a side chain and not as part of a seven-membered ring as in 1-3. Furthermore, the methoxy group $\mathrm{OCH}_{3}-28\left(\delta_{\mathrm{C}} 52.0\right)$ correlated with an ester carbonyl carbon resonating at $\delta_{\mathrm{C}} 177.7$ which was assigned to C-17. H-21 correlated with $\mathrm{CH}_{2}-19, \mathrm{C}-20, \mathrm{CH}_{3}-27, \mathrm{CH}_{2}-22\left(\delta_{\mathrm{C}} 18.5\right)$, and C-6 $\left(\delta_{\mathrm{C}} 118.0\right) . \mathrm{CH}_{2}-22$ correlated with $\mathrm{C}-20, \mathrm{CH}-21, \mathrm{C}-6$, as well as with the oxygenated quaternary carbons $\mathrm{C}-5\left(\delta_{\mathrm{C}} 158.1\right)$, C-7 $\left(\delta_{\mathrm{C}} 160.0\right)$ and C-11 $\left(\delta_{\mathrm{C}} 78.3\right)$. Correlations of the tertiary methyl group $\mathrm{CH}_{3}-24$ $\left(\delta_{\mathrm{C}} 27.9\right)$ with $\mathrm{C}-11, \mathrm{C}-21$ and $\mathrm{CH}_{2}-12\left(\delta_{\mathrm{C}} 40.2\right)$ provided the remaining connections of the spin systems previously observed in the ${ }^{1} \mathrm{H}-{ }^{1} \mathrm{H}$ COSY spectrum. The methoxy group $\mathrm{OCH}_{3}-29\left(\delta_{\mathrm{C}} 62.1\right)$ was attached to $\mathrm{C}-5$ as indicated by the respective HMBC correlation. The aromatic $\mathrm{CH}_{3}-23\left(\delta_{\mathrm{C}} 10.6\right)$ correlated to the quaternary aromatic carbons C-7, C-8 $\left(\delta_{\mathrm{C}} 117.3\right)$, and C-9 $\left(\delta_{\mathrm{C}} 148.0\right)$, and hence was placed at C-8. The remaining ${ }^{13} \mathrm{C}$ resonances at $\delta_{\mathrm{C}} 108.0$ and 172.1 were attributed to C-4 and C-3, respectively. This was further confirmed by correlation of C-9 with $\mathrm{CH}_{2}-1\left(\delta_{\mathrm{C}} 69.8\right)$, 
which in turn correlated with C-8, C-4 and C-3. Accordingly, 4 shows familiar features to 1-3 except for that the seven-membered ring of 1-3 was opened at the oxo-bridges giving rise to 2 side chains located at C-20 and C-14 instead.

The relative configuration of $\mathbf{4}$ was established by interpretation of the ROESY spectrum. By analogy with $\mathbf{1}, \mathrm{CH}_{3}-24$ correlated with $\mathrm{H}-21$ thus denoting cis-fusion of rings $\mathrm{C}$ and $\mathrm{D}$. This was further confirmed by correlations observed for H-21 with $\mathrm{H}-14$ and $\mathrm{CH}_{3}-24$, indicating the cis orientation of $\mathrm{H}-21$ and $\mathrm{H}-14$. A trans relationship between $\mathrm{CH}_{3}-24$ and -27 was assumed from the absence of correlations between $\mathrm{CH}_{3}-27$ and $\mathrm{H}-14, \mathrm{H}-21$ or $\mathrm{CH}_{3}-24$. Accordingly, the relative stereochemistry of 4 was determined as $\left(11 S^{*}, 14 R^{*}, 20 S^{*}, 21 R^{*}\right)$. Compound 4 lacked the benzylic chirality center and its ECD spectrum was completely different from that of $\mathbf{1}$, which implied that ECD calculation was required for the configurational assignment. The ECD spectrum of 4 showed four main ECD bands at 267, 228, 212 and $194 \mathrm{~nm}$ with alternating negative, positive, negative, positive CEs, respectively (Figure 7). The MMFF conformational search followed by B3LYP/6-31G(d) DFT reoptimization of 31 conformers afforded four conformational isomers with $40.0 \%, 23.5 \%, 16.8 \%$ and $15.1 \%$ populations above $2 \%$ populations. Besides slightly different orientations of the side-chains, the value of the torsional angle $\omega_{\mathrm{O} 3, \mathrm{C} 3, \mathrm{C} 4, \mathrm{C} 9}$ was identified as the main difference among the conformers (Figure 8). In contrast to the situation for austalide M (1), the two lowest-energy conformers had positive torsional angle $\omega_{\mathrm{O} 3, \mathrm{C} 3, \mathrm{C} 4, \mathrm{C} 9}$, while the two higher-energy ones had negative ones. In accordance conformer A and $\mathrm{B}$ gave nearly identical calculated ECDs and different from those of conformer $\mathrm{C}$ and $\mathrm{D}$, which were similar. The Boltzmann-weighted ECD spectra of $(11 S, 14 R, 20 S, 21 R)-4$ computed with TZVP basis set and three different functionals (B3LYP, BH\&HLYP, PBE0) reproduced well the experimental ECD spectrum with PBE0 giving the best agreement (Figure 8). Thus the absolute configuration of $\mathbf{4}$ was unambiguously determined as (-)-(11S,14R,20S,21R) and it was named as austalide $\mathrm{P}$. The ECD 
calculation also revealed that the sign of the torsional angle $\omega_{\mathrm{O} 3, \mathrm{C} 3, \mathrm{C} 4, \mathrm{C} 9}$, i.e. the conformation of the benzene-fused pthalide ring, is decisive for the ECD parameters. The major conformers of austalide M (1) and P (4) had oppositely signed torsional angles $\omega_{\mathrm{O} 3, \mathrm{C} 3, \mathrm{C} 4, \mathrm{C} 9}$, which resulted in markedly different ECD spectra. The torsional angle $\omega_{\mathrm{O} 3, \mathrm{C} 3, \mathrm{C} 4, \mathrm{C} 9}$ of the conformers and their populations are clearly determined by the central chirality elements and the benzylic C-22 chirality center has obviously a determining role. The results of the ECD calculation also explain the fact that the ECD spectra (Figure 9) of austalide N (2) and O (3) were different from that of austalide M (1), although they are homochiral and they differ only in the nature of the benzylic C-22 substituent. The nature of the benzylic C-22 substituent (methoxy, acetoxy or hydroxyl) has an effect on the torsional angle $\omega_{\mathrm{O} 3, \mathrm{C} 3, \mathrm{C} 4, \mathrm{C} 9}$ of the conformers and their populations, which in turn determines the ECD parameters. The examples of austalides suggest that a simple comparison of their ECD spectra, a general procedure for the determination of absolute configuration for structurally related compounds, can not be used safely in the presence of a chirally perturbed benzene-fused phtalide chromophore.

The HRESIMS of 5 exhibited a prominent peak at $m / z 459.2376[\mathrm{M}+\mathrm{H}]^{+}$ indicating a molecular formula of $\mathrm{C}_{26} \mathrm{H}_{34} \mathrm{O}_{7}$. The ${ }^{1} \mathrm{H},{ }^{13} \mathrm{C}$ NMR and DEPT data of 5 (Tables 2 and 3) were similar to those of $\mathbf{4}$ apart from the replacement of one of the methylene protons at $\mathrm{C}-13$ by a hydroxyl group in $\mathbf{5}$, as evidenced by the chemical shifts of $\mathrm{CH}-13\left(\delta_{\mathrm{H}} 4.11, \delta_{\mathrm{C}} 72.2\right)$. In addition, the hydroxyl group at $\mathrm{C}-15$ of $\mathbf{4}$ was absent and one of the geminal methyl groups was replaced by an olefinic methylene group, the protons of which resonate downfield at $\delta_{\mathrm{H}} 4.96$ and $5.05 \mathrm{ppm}\left(\mathrm{CH}_{2}-25\right)$. This was further confirmed by the analysis of the ${ }^{1} \mathrm{H}-{ }^{1} \mathrm{H}$ COSY spectrum (Table 2) which verified the fragment $\mathrm{CH}_{2}(12) \mathrm{CH}(13) \mathrm{CH}(14)$ derived from the correlations observed between the methylene protons at $\delta_{\mathrm{H}} 2.02$ and $2.41 \mathrm{ppm}\left(\mathrm{CH}_{2}-12\right)$, the proton at C-13, and $\mathrm{H}-14$ detected at $2.20 \mathrm{ppm}$. HMQC and HMBC spectra (Table 2) 
gave further evidence for the assigned partial structures of $\mathbf{5}$. The correlations observed for $\mathrm{CH}_{3}-26\left(\delta_{\mathrm{H}} 1.90\right)$ to $\mathrm{C}-14\left(\delta_{\mathrm{C}} 54.3\right)$, the olefinic quaternary carbon detected at $\delta_{\mathrm{C}} 148.0(\mathrm{C}-15)$, and an olefinic methylene carbon at $\delta_{\mathrm{C}} 116.2 \mathrm{ppm}(\mathrm{C}-25)$, confirmed the dehydrogenation of the C-15-C-25 bond in 5 compared to that of 4 . The ROESY spectrum of $\mathbf{5}$ showed similar correlations to those of $\mathbf{4}$ indicating $\left(11 S^{*}, 13 R^{*}, 14 S^{*}, 20 S^{*}, 21 R^{*}\right)$ relative configuration, which regarding the corresponding chirality centers, was homochiral with that of austalide M (1). Since compound $\mathbf{5}$ exhibited nearly identical ECD spectrum with that of $\mathbf{4}$ and the C-11 and C-21 chirality centers, the closest ones to the substituted chroman chromophore, were the same, its absolute configuration was determined as (-)-(11S,13R,14S,20S,21R) and it was named austalide Q.

The main structural difference between the new austalides M-Q (1-5) and previously reported austalides with the same molecular framework is the presence of an additional substituent at C-22 in $\mathbf{1 - 3}$, compared to the known austalides A-F. ${ }^{[13,14]}$ Furthermore, austalide $\mathrm{P}(4)$ lacks a substituent at C-13 having a methylene group in this position, whereas austalide Q (5) features a C-15-C25 double bond, compared to the structurally related austalides $\mathrm{G}$ and $\mathrm{H} .{ }^{[13,14]}$

Compounds 1-13 were evaluated for their cytotoxic activity against the murine cancer cell line L5178Y by the MTT assay. ${ }^{[36]}$ Only compound 8 exhibited pronounced cytotoxicity with an $\mathrm{IC}_{50}$ values of $0.2 \mu \mathrm{M}$. Compound 11 showed moderate activity $\left(\mathrm{IC}_{50} 39.4 \mu \mathrm{M}\right)$, whereas the remaining compounds showed weak or no activity in the assay (Table 4).

\section{Experimental Section}

General Experimental Procedures: Optical rotations were determined on a Perkin-Elmer-241 MC polarimeter and CD spectra were recorded on a J-810 CD spectropolarimeter. ${ }^{1} \mathrm{H},{ }^{13} \mathrm{C}$, and two-dimensional NMR spectra were recorded in 
methanol- $d_{4}$ on Bruker ARX 400 or Bruker ARX 500 NMR spectrometers. ESIMS was conducted on a Finnigan LCQ Deca mass spectrometer, and HRESIMS spectra were obtained on a FTHRMS-Orbitrap (Thermo-Finnigan) mass spectrometer. Solvents were distilled prior to use, and spectral grade solvents were used for spectroscopic measurements. HPLC analysis was performed using a Dionex P580 system coupled to a photodiode array detector (UVD340S). Routine detection was at 235, 254, 280, and $340 \mathrm{~nm}$. The separation column $(125 \times 4 \mathrm{~mm}$, Lxi.d.) was prefilled with Eurospher-10 $\mathrm{C}_{18}$ (Knauer, Germany), and the following gradient was used $\left(\mathrm{MeOH}, 0.02 \% \mathrm{H}_{3} \mathrm{PO}_{4}\right.$ in $\mathrm{H}_{2} \mathrm{O}$ ): 0 min, $10 \% \mathrm{MeOH} ; 5$ min, $10 \% \mathrm{MeOH} ; 35 \mathrm{~min}$, $100 \% \mathrm{MeOH} ; 45 \mathrm{~min}, 100 \% \mathrm{MeOH}$. TLC plates with silica gel $\mathrm{F}_{254}$ (Merck, Darmstadt, Germany) were used for monitoring of fractions using dichloromethane/methanol-based solvent systems. Detection was at 254 and $366 \mathrm{~nm}$ or by spraying the plates with anisaldehyde reagent.

Fungal material: The sponge Tethya aurantium, collected from the Mediterranean Sea near Italy, was surface sterilized by immersing in $70 \%$ ethanol for $30 \mathrm{sec}$ followed by rinsing three times in sterilized artificial sea water. Then, the sponge was cleaved aseptically into small segments $(\approx 1.5 \times 1.5 \mathrm{~mm})$. The material was placed on a potato carrot agar medium and incubated at room temperature $\left(25^{\circ} \mathrm{C}\right)$. After several days hyphae growing from the sponge material were transferred to fresh plates with the same medium, incubated again and periodically checked for culture purity. The fungus was identified as Aspergillus sp. (Moniliaceae) using a molecular biological protocol ${ }^{[37]}$ as well as by morphological characterization.

Cultivation: Mass growth of the fungus for the isolation and identification of secondary metabolites was carried out on two different media, namely biomalt agar and spelt barley (composed of $200 \mathrm{~g}$ barley, $200 \mathrm{~g}$ spelt, $2 \mathrm{~g}$ soy protein, $2 \mathrm{mg} \mathrm{MnCl}_{2}$ 
und $250 \mathrm{~mL}$ distilled water) solid media for 21 days at $22{ }^{\circ} \mathrm{C}$. The cultures obtained from both media were then lyophilized, extracted with ethyl acetate, and the dry residues left after evaporation were defatted with petroleum ether.

Extraction and Isolation: The culture media were extracted with ethyl acetate to afford $35 \mathrm{~g}$ of dry residue after removal of solvent under reduced pressure. The EtOAc extract was then partitioned between $n$-hexane and $90 \% \mathrm{MeOH}$, the latter yielding $18.0 \mathrm{~g}$ dry residue. This residue was subjected to vacuum liquid chromatography (VLC) on silica gel employing a step gradient of dichloromethane/methanol to yield ten fractions (F1-F10). Fraction F2 (1.7 g) was subjected to chromatographic separation using HP-20 with a step gradient of water/methanol to yield 10. Sub-fractions were chromatographed on Sephadex LH-20 with methanol as eluting solvent. Based on detection by TLC, fractions were combined and subjected to semi-preparative HPLC (Merck, Hitachi L-7100) using a Eurosphere $100-10 \mathrm{C}_{18}$ column $(300 \times 8 \mathrm{~mm}$, Lxi.d.) with an eluting gradient of $\mathrm{MeOH} / \mathrm{H}_{2} \mathrm{O}$. Yields of compounds were as follows: $18.5 \mathrm{mg}, 28.0 \mathrm{mg}, 34.5 \mathrm{mg}, 4$ $4.5 \mathrm{mg}, \mathbf{5} 1.6 \mathrm{mg}, \mathbf{6} 11.0 \mathrm{mg}, \mathbf{7} 28.0 \mathrm{mg}, \mathbf{8} 7.5 \mathrm{mg}, \mathbf{9} 6.0 \mathrm{mg}, \mathbf{1 0} 120.0 \mathrm{mg}, \mathbf{1 2} 1.9 \mathrm{mg}$, and $134.5 \mathrm{mg}$. Similarly, fraction F6 (771.6 mg) was chromatographed on Sephadex LH-20 with methanol as eluting solvent followed by semi-preparative HPLC to yield $114.5 \mathrm{mg}$.

Austalide M (1): brown amorphous solid (MeOH); $[\alpha]^{20}{ }_{\mathrm{D}}-43(c 0.35, \mathrm{MeOH})$; $\mathrm{UV}\left(\mathrm{MeOH} / \mathrm{H}_{2} \mathrm{O}\right) \lambda_{\max } 223.7,267.8 \mathrm{~nm}$; ECD $\left.(\mathrm{MeCN}), \lambda[\mathrm{nm}](\Delta \varepsilon), c=2.1 \times 10^{-4}\right)$ : $301(-0.23), 295$ (0.14), 262 (-2.07), $217(-16.00), 196$ (5.61). ${ }^{1} \mathrm{H}$ and ${ }^{13} \mathrm{C}$ NMR data, see Tables 1 and 3; ESIMS positive $m / z 504.9[\mathrm{M}+\mathrm{H}]^{+}, 527.1[\mathrm{M}+\mathrm{Na}]^{+}$; HRESIMS $m / z 505.2423[\mathrm{M}+\mathrm{H}]^{+}$(calc. for $\mathrm{C}_{27} \mathrm{H}_{37} \mathrm{O}_{9}, 505.2438$ ).

Austalide N (2): brown amorphous solid (MeOH); $[\alpha]^{20}{ }_{\mathrm{D}}-15(c 0.40, \mathrm{MeOH})$; $\left.\mathrm{UV}\left(\mathrm{MeOH} / \mathrm{H}_{2} \mathrm{O}\right) \lambda_{\max } 223.9,266.9 \mathrm{~nm} ; \mathrm{ECD}(\mathrm{MeCN}), \lambda[\mathrm{nm}](\Delta \varepsilon), c=3.1 \times 10^{-4}\right):$ 
300sh (0.15), 284sh (-0.25), 264 (-0.92), 231 (-2.29), 224sh (-2.00), $201(0.11) .{ }^{1} \mathrm{H}$ and ${ }^{13} \mathrm{C}$ NMR data, see Tables 1 and 3; ESIMS positive $m / z, 532.8[\mathrm{M}+\mathrm{H}]^{+}, 554.9[\mathrm{M}$ $+\mathrm{Na}]^{+}$; HRESIMS $m / z$ 533.2388 $[\mathrm{M}+\mathrm{H}]^{+}$(calc. for $\mathrm{C}_{28} \mathrm{H}_{37} \mathrm{O}_{10}, 533.2387$ ).

Austalide O (3): brown amorphous solid (MeOH); $[\alpha]^{20}{ }_{\mathrm{D}}-41(c$ 0.15, MeOH); $\mathrm{UV}\left(\mathrm{MeOH} / \mathrm{H}_{2} \mathrm{O}\right) \lambda_{\max } 222.8,268.4 \mathrm{~nm}$; ECD $\left.(\mathrm{MeCN}), \lambda[\mathrm{nm}](\Delta \varepsilon), c=3.4 \times 10^{-4}\right)$ : 296 (0.35), 260sh (-1.25), 245 (-1.60), 225sh (1.77), 212 (5.02). ${ }^{1} \mathrm{H}$ and ${ }^{13} \mathrm{C}$ NMR data, see Tables 1 and 3; ESIMS positive $m / z 490.8[\mathrm{M}+\mathrm{H}]^{+}, 513.1[\mathrm{M}+\mathrm{Na}]^{+}$; HRESIMS $m / z 491.2293[\mathrm{M}+\mathrm{H}]^{+}$(calc. for $\mathrm{C}_{26} \mathrm{H}_{35} \mathrm{O}_{9}, 491.2281$ ).

Austalide P (4): brown amorphous solid (MeOH); $[\alpha]^{20}{ }_{\mathrm{D}}-35(c 0.15, \mathrm{MeOH})$; $\mathrm{UV}\left(\mathrm{MeOH} / \mathrm{H}_{2} \mathrm{O}\right) \lambda_{\max } 221.7,270.1 \mathrm{~nm}$; ECD $\left.(\mathrm{MeCN}), \lambda[\mathrm{nm}](\Delta \varepsilon), c=3.6 \times 10^{-4}\right)$ : 295sh (-0.92), 267 (-4.41), 239sh (-1.10), 228 (4.01), 212 (-4.43), 194 (2.28). ${ }^{1} \mathrm{H}$ and ${ }^{13} \mathrm{C}$ NMR data, see Tables 2 and 3; ESIMS positive $m / z 460.8[\mathrm{M}+\mathrm{H}]^{+}, 483.1[\mathrm{M}+$ $\mathrm{Na}]^{+}, 943.0[2 \mathrm{M}+\mathrm{Na}]^{+} ;$HRESIMS $m / z 461.2532[\mathrm{M}+\mathrm{H}]^{+}, 483.2349[\mathrm{M}+\mathrm{Na}]^{+}$ (calc. for $\mathrm{C}_{26} \mathrm{H}_{37} \mathrm{O}_{7}, 461.2539$ ).

Austalide Q (5): brown amorphous solid (MeOH); $[\alpha]^{20}{ }_{\mathrm{D}}-40(c 0.16, \mathrm{MeOH})$; $\mathrm{UV}\left(\mathrm{MeOH} / \mathrm{H}_{2} \mathrm{O}\right) \lambda_{\max } 220.5,267.7 \mathrm{~nm}$; ECD $\left.(\mathrm{MeCN}), \lambda[\mathrm{nm}](\Delta \varepsilon), c=2.6 \times 10^{-4}\right)$ : 294sh (-0.31), 263 (-2.01), 239sh (-0.37), 226 (2.78), 208 (-1.58), 194 (1.57). ${ }^{1} \mathrm{H}$ and ${ }^{13} \mathrm{C}$ NMR data, see Tables 2 and 3; ESIMS positive $m / z 459.0[\mathrm{M}+\mathrm{H}]^{+}, 481.1[\mathrm{M}+$ $\mathrm{Na}]^{+}, 939.1[2 \mathrm{M}+\mathrm{Na}]^{+} ; \operatorname{HRESIMS~} m / z$ 459.2376 $[\mathrm{M}+\mathrm{H}]^{+}, 481.2195[\mathrm{M}+\mathrm{Na}]^{+}$ (calc. for $\mathrm{C}_{26} \mathrm{H}_{35} \mathrm{O}_{7}, 459.2383$ ).

Cell Proliferation Assay: Cytotoxicity was tested against L5178Y mouse lymphoma cells using a microculture tetrazolium (MTT) assay and compared to that of untreated controls as described previously. ${ }^{[38,39]}$ Experiments were repeated three times and carried out in triplicate. As negative controls, media with $0.1 \%$ EGMME/DMSO were included in the experiments. The depsipeptide kahalalide F isolated from Elysia grandifolia ${ }^{[38]}$ was used as positive control. 
Computational section: Conformational searches were carried out by means of the Macromodel 9.7.211 ${ }^{[40]}$ software using Merck Molecular Force Field (MMFF) with implicit solvent model for chloroform. Geometry reoptimizations at B3LYP/6-31G(d) level of theory followed by TDDFT calculations using various functionals (B3LYP, BH\&HLYP, PBE0) and TZVP basis set were performed by the Gaussian $03^{[41]}$ package. Boltzmann distributions were estimated from the ZPVE corrected B3LYP/6-31G(d) energies. CD spectra were generated as the sum of Gaussians ${ }^{[42]}$ with $3000 \mathrm{~cm}^{-1}$ half-height width (corresponding to ca. $16 \mathrm{~nm}$ at 230 $\mathrm{nm})$, using dipole-velocity computed rotational strengths for conformers above $3 \%$. The MOLEKEL ${ }^{[43]}$ software package was used for visualization of the results.

Acknowledgment: Financial support by grants of BMBF and MOST to P. P. and W. L. is gratefully acknowledged. Y. M. Z. wishes to thank China Scholarship Council, the Ministry of Education of China, for a scholarship. We are indebted to C. Kakoschke for NMR measurements (HZI, Braunschweig, Germany). T. K. thanks the National Office for Research and Technology (NKTH, K-68429), TÁMOP 4.2.1./B-09/1/KONV-2010-0007 and János Bolyai Foundation. 


\section{References}

[1] M. A. Abdel-Wahab, R. N. Asolkar, P. Inderbitzin, W. Fenical, Phytochemistry 2007, 68, 1212-1218.

[2] M. E. Rateb, R. Ebel, Nat. Prod. Rep. 2011, 28, 290-344.

[3] E. P. Abraham, P. B. Loder, Cephalosporins and penicillins; chemistry and biology, E. H. Flynn (ed.), Academic Press, New York, 1972, p. 1-26.

[4] M. P. Lopez-Gresa, N. Cabedo, M. C. Gonzalez-Mas, M. L. Ciavatta, C. Avila, J. Primo, J. Nat. Prod. 2009, 72, 1348-1351.

[5] G.. Bringmann, G.. Lang, S. Steffens, K. Schaumann, J. Nat. Prod. 2004, 67, $311-315$.

[6] M. Daferner, T. Anke, O. Sterner, Tetrahedron 2002, 58, 7781-7784.

[7] J. He, W. E. M. Kithsiri, B. P. Bashyal, J. Zhan, C. J. Seliga, M. X. Liu, E. E. Pierson, L. S. Piesron, H. D. Vanetten, A. A. L. Gunatilaka, J. Nat. Prod. 2004, 67, 1985-1991.

[8] H. Liu, R. Edrada-Ebel, R. Ebel, Y. Wang, B. Schulz, S. Draeger, W.E.G. Müller, V. Wray, W. Lin, P. Proksch, J. Nat. Prod. 2009, 72, 1585-1588.

[9] K. Kito, R. Ookura, S. Yoshida, M. Namikoshi, T. Ooi, T. Kusumi, J. Nat. Prod. 2007, 70, 2022-2025.

[10] Z. Lu, Y. Wang, C. Miao, P. Liu, K. Hong, W. Zhu, J. Nat. Prod. 2009, 72, 1761-1767.

[11] A. N. Yurchenko, O. F. Smetanina, A. I. Kalinovsky, M. V. Pivkin, P. S. Dmitrenok, T. A. Kuznetsova, Russ. Chem. Bull. 2010, 59, 852-856.

[12] J. Zheng, Z. Xu, Y. Wang, K. Hong, P. Liu, W. Zhu, J. Nat. Prod. 2010, 73, 1133-1137.

[13] R.M. Horak, P. S. Steyn, R. Vleggaar, J. Chem. Soc. Perkin Trans. I 1985, $345-356$.

[14] R.M. Horak, P. S. Steyn, R. Vleggaar, J. Chem. Soc. Perkin Trans. I 1985, $363-367$.

[15] R.M. Horak, P. S. Steyn, P.H. Van Rooyen, R. Vleggaar, J. Chem. Soc. Chem. Comm. 1981, 1265-1267.

[16] H. G. Cutler, F. G. Crumley, J. P. Springer, R. H. Cox, J. Agric. Food Chem. 1981, 29, 981-983. 
[17] J. Kohno, H. Hiramatsu, M. Nishio, M. Sakurai, T. Okuda, S. Komatsubara, Tetrahedron 1999, 55, 11247-11252.

[18] J. Kohno, M. Sakurai, N. Kameda, M. Nishio, K. Kawano, N. Kishi, T. Okuda, S. Komatsubara, J. Antibiot. 1999, 52, 913-916.

[19] M. A. Hayes, S. K. Wrigley, I. Chetland, E. E. Reynolds, A. M. Ainsworth, D. V. Renno, M. A. Latif, X.-M. Cheng, D. J. Hupe, P. Charlton, A. M. Doherty, J. Antibiot. 1996, 49, 505-512.

[20] J. Xu, J. Kjer, J. Sendker, V. Wray, H. Guan, R. A. Edrada, W. H. Lin, J. Wu, P. Proksch, J. Nat. Prod. 2009, 72, 662-665.

[21] H. B. Liu, R. A. Edrada-Ebel, R. Ebel, Y. Wang, B. Schulz, S. Draeger, W. E. G. Müller, V. Wray, W. H. Lin, P. Proksch, Helv. Chim. Acta. 2011, 94, 623-631.

[22] K. Krohn, U. Floerke, M. S. Rao, K. Steingroever, H. J. Aust, S. Draeger, B. Schulz, Nat. Prod. Lett. 2001, 15, 353-361.

[23] C. H. Chen, C. Y. Shaw, C. C. Chen, Y. C. Tsai, J. Nat. Prod. 2002, 67, 740-741.

[24] D. A. Mulholland, P. Cheplogoi, N. R. Crouch, Biochem. Sys. Ecol. 2003, 31, 793-797.

[25] R. Thomas, G.. Hans, Liebigs Ann. 1995, 885-888.

[26] K. V. Rao, A. K. Sadhukhan, M. Veerender, V. Ravikumar, E. V. S. Mohan, S. D. Dhanvantri, M. Sitaramkumar, J. Moses Babu, K. Vyas, G. Om Reddy, Chem. Pharm. Bull. 2000, 48, 559-562.

[27] K. Nitta, N. Fujita, T. Yoshimura, K. Aral, Y. Yamamoto, Chem. Pharm. Bull. 83, $31,1528-1533$.

[28] K. Arai, S. Shimizu, Y. Yamamoto, Chem. Pharm. Bull. 1981, 29, 1005-1012.

[29] J. Barber, J. L. Cornford, T. D. Haoward, D. J. Sharples, Chem. Soc. Perkin Trans. I 1987, 2743-2744.

[30] B. R. Clark, R. J. Capon, E. Lacey, S. Tennant, J. H. Gill, Org. Biomol. Chem. 2006, 4, 1520-1528.

[31] D. Wakana, T. Hosoe, T. Itabashi, K. Okada, G. M. C. Takaki, T. Yaguchi, K. Fukushima, K. Kawai, J. Nat. Med. 2006, 60, 279-284.

[32] Y. Yamamoto, K. Nitta, K. Tango, T. Saito, M. Tsuchimuro, Chem. Pharm. Bull. 1965, 13, 935-941. 
[33] M. Karplus, J. Am. Chem. Soc. 1963, 85, 2870-2871.

[34] S. Antus, T. Kurtán, L. Juhász, L. Kiss, M. Hollósi, Zs. Májer, Chirality 2001, 13, 493-506.

[35] J. L. M. Dillen, R. M. Horak, V. J. Maharaj, S. F. Marais, R. Vleggaar, J. Chem. Soc. Chem. Comm. 1989, 393-394.

[36] A. H. Aly, R. A. Edrada-Ebel, I. D. Indriani, V. Wray, W. E. G. Mueller, W. H. Lin, P. Proksch, R. Ebel, J. Nat. Prod. 2008, 71, 972-980.

[37] S. Wang, X. M. Li, F. Teuscher, D. L. Li, A. Diesel, R. Ebel, P. Proksch, B. G..Wang, J. Nat. Prod. 2006, 69, 1622-1625.

[38] M. Ashour, R. A. Edrada-Ebel, R. Ebel, V. Wray, W. Waetjen, K. Padmakumar, W. E. G. Mueller, W. H. Lin, P. Proksch, J. Nat. Prod. 2006, 69, 1547-1553.

[39] J. Carmichael, W. G.. Degraff, A. F. Gazdar, J. D. Minna, J. B. Mitchell, Cancer Res. 1987, 47, 943-946.

[40] MacroModel, Schrödinger LLC, 2009.

http://www.schrodinger.com/Products/macromodel.html

[41]M. J. Frisch, G. W. Trucks, H. B. Schlegel, G. E. Scuseria, M. A. Robb, J. R. Cheeseman, J. A. Montgomery Jr., T. Vreven, K. N. Kudin, J. C. Burant, J. M. Millam, S. S. Iyengar, J. Tomasi, V. Barone, B. Mennucci, M. Cossi, G.. Scalmani, N. Rega, G. A. Petersson, H. Nakatsuji, M. Hada, M. Ehara, K. Toyota, R. Fukuda, J. Hasegawa, M. Ishida, T. Nakajima, Y. Honda, O. Kitao, H. Nakai, M. Klene, X. Li, J. E. Knox, H. P. Hratchian, J. B. Cross, V. Bakken, C. Adamo, J. Jaramillo, R. Gomperts, R. E. Stratmann, O. Yazyev, A. J. Austin, R. Cammi, C. Pomelli, J. W. Ochterski, P. Y. Ayala, K. Morokuma, G. A. Voth, P. Salvador, J. J. Dannenberg, V. G. Zakrzewski, S. Dapprich, A. D. Daniels, M. C. Strain, O. Farkas, D. K. Malick, A. D. Rabuck, K. Raghavachari, J. B. Foresman, J. V. Ortiz, Q. Cui, A. G. Baboul, S. Clifford, J. Cioslowski, B. B. Stefanov, G. Liu, A. Liashenko, P. Piskorz, I. Komaromi, R. L. Martin, D. J. Fox, T. Keith, M. A. Al-Laham, C. Y. Peng, A. Nanayakkara, M. Challacombe, P. M. W. Gill, B. Johnson, W. Chen, M. W. Wong, C. Gonzalez, J. A. Pople, Gaussian 03, Revision C.02., Gaussian Inc., Wallingford CT, 2004.

[42]P. J. Stephens, N. Harada, Chirality 2010, 22, 229-233.

[43]U. Varetto, MOLEKEL 5.4., Swiss National Supercomputing Centre: Manno, Switzerland, 2009. 


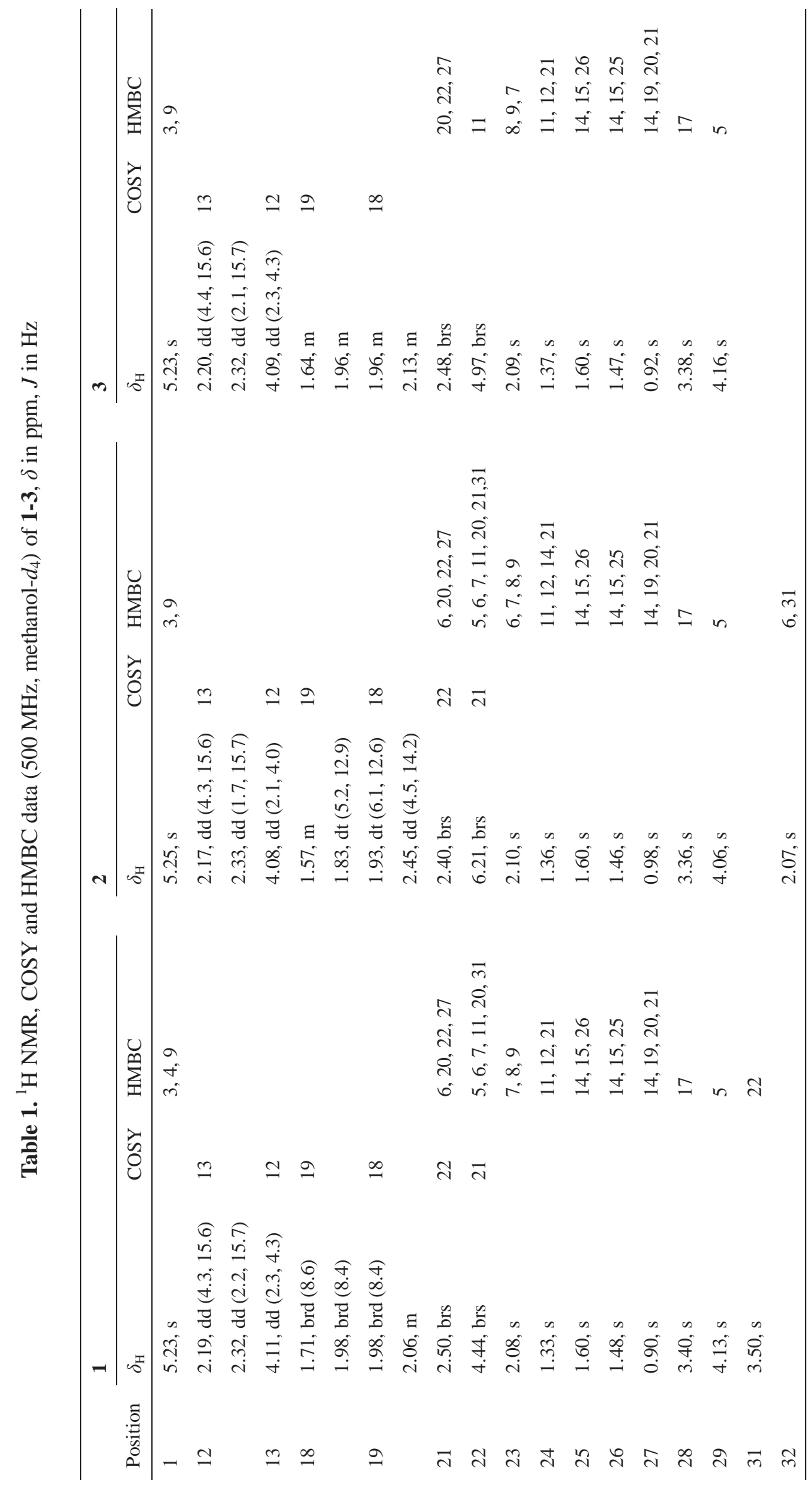




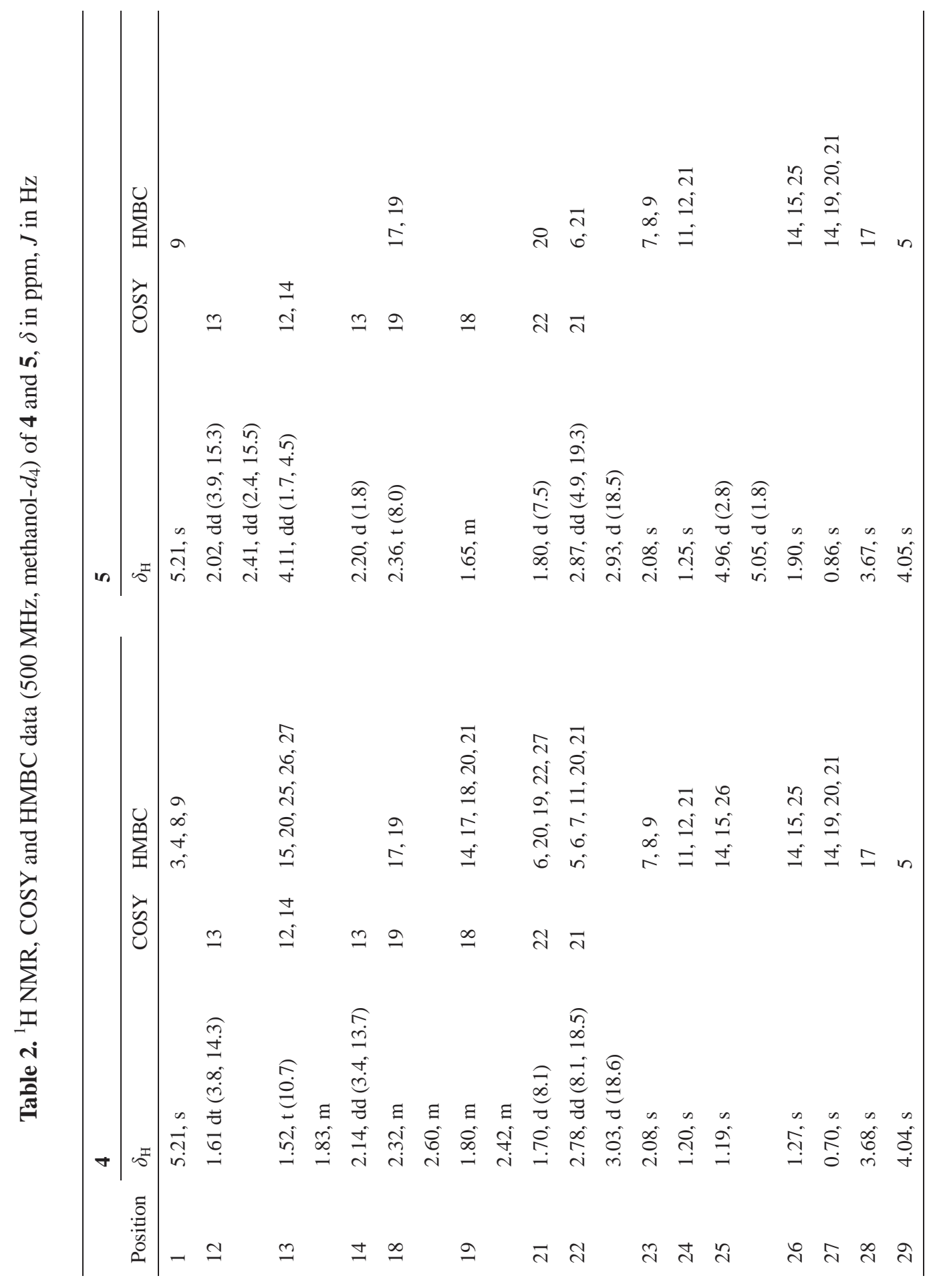


Table 3. ${ }^{13} \mathrm{C}$ NMR data (methanol- $d_{4}$ ) of $\mathbf{1 - 5}, \delta$ in ppm

\begin{tabular}{|c|c|c|c|c|c|}
\hline Position & $1^{a}$ & $2^{a}$ & $3^{a}$ & $4^{b}$ & $5^{b}$ \\
\hline 1 & 70.0 & 69.9 & 69.9 & 69.8 & 70.7 \\
\hline 3 & 171.5 & 171.2 & 172.0 & 172.1 & 172.1 \\
\hline 4 & 108.9 & 108.5 & 108.8 & 108.0 & 108.0 \\
\hline 5 & 158.9 & 158.4 & 158.5 & 158.1 & 154.7 \\
\hline 6 & 119.4 & 116.0 & 116.0 & 118.0 & 118.0 \\
\hline 7 & 158.9 & 159.6 & 159.2 & 160.0 & 160.0 \\
\hline 8 & 116.2 & 116.4 & 116.1 & 117.3 & 117.3 \\
\hline 9 & 149.3 & 150.1 & 149.2 & 148.0 & 146.2 \\
\hline 11 & 77.3 & 77.1 & 77.1 & 78.3 & 79.3 \\
\hline 12 & 43.8 & 43.7 & 43.8 & 40.2 & 46.6 \\
\hline 13 & 69.9 & 69.6 & 70.0 & 22.4 & 72.2 \\
\hline 14 & 87.7 & 87.6 & 87.6 & 40.1 & 54.3 \\
\hline 15 & 86.1 & 85.1 & 86.2 & 75.7 & 148.0 \\
\hline 17 & 120.3 & 120.6 & 120.5 & 177.7 & 176.7 \\
\hline 18 & 32.0 & 32.0 & 31.8 & 30.0 & 29.9 \\
\hline 19 & 31.4 & 31.6 & 31.8 & 34.9 & 36.0 \\
\hline 20 & 39.8 & 40.9 & 40.1 & 41.6 & 40.1 \\
\hline 21 & 43.6 & 46.3 & 48.0 & 41.2 & 40.7 \\
\hline 22 & 72.2 & 65.3 & 62.0 & 18.5 & 18.9 \\
\hline 23 & 10.7 & 10.6 & 10.8 & 10.6 & 10.8 \\
\hline 24 & 28.8 & 28.8 & 29.2 & 27.9 & 27.8 \\
\hline 25 & 26.5 & 26.4 & 26.4 & 28.0 & 116.2 \\
\hline 26 & 29.2 & 29.2 & 29.0 & 33.2 & 26.4 \\
\hline 27 & 19.2 & 19.2 & 19.0 & 19.5 & 20.7 \\
\hline 28 & 49.0 & 50.1 & 50.0 & 52.0 & 52.4 \\
\hline 29 & 63.3 & 63.1 & 62.2 & 62.1 & 62.7 \\
\hline 31 & 56.4 & 171.6 & & & \\
\hline 32 & & 21.3 & & & \\
\hline
\end{tabular}

${ }^{a 13} \mathrm{C}$ NMR (100 MHz) $\quad{ }^{b 13} \mathrm{C}$ NMR (150 MHz) 
Table 4. Results of cytotoxicity assay for the isolated compounds

\begin{tabular}{|c|c|c|c|c|}
\hline Compound tested & & $\begin{array}{l}\text { L5178Y growth } \\
\text { inhibition in } \% \\
\text { (at } 10 \mu \mathrm{g} / \mathrm{mL} \text { ) }\end{array}$ & $\begin{array}{c}\mathrm{IC}_{50} \\
(\mu \mathrm{g} / \mathrm{mL})\end{array}$ & $\begin{array}{l}\mathrm{IC}_{50} \\
(\mu \mathrm{M})\end{array}$ \\
\hline Austalide M & (1) & 0 & & \\
\hline Austalide $\mathrm{N}$ & (2) & 0 & & \\
\hline Austalide $\mathrm{O}$ & (3) & 28.0 & & \\
\hline Austalide P & (4) & 16.2 & & \\
\hline Austalide Q & (5) & 41.7 & & \\
\hline 4-acetyl-3,4-dihydro-6,8-dihydroxy-3-methoxy-5-methylisocoumarin & (6) & 9.3 & & \\
\hline 2,3,4-trimethyl-5,7-dihydroxy-2,3-dihydrobenzofuran & (7) & 9.1 & & \\
\hline 4-acetyl-3,4-dihydro-6,8-dihydroxy-5-methylisocoumarin & (8) & 76.9 & 9.3 & 39.4 \\
\hline Phenol A acid & $(9)$ & 0 & & \\
\hline Butyrolactone II & (10) & 49.1 & & \\
\hline Methyl 3,4,5-trimethoxy-2-(2-nicotinamidobenzamido)benzoate & (11) & 100.1 & 0.1 & 0.2 \\
\hline Citrinin & $(12)$ & 35.8 & & \\
\hline Dicitrinin A & (13) & 44.6 & & \\
\hline
\end{tabular}




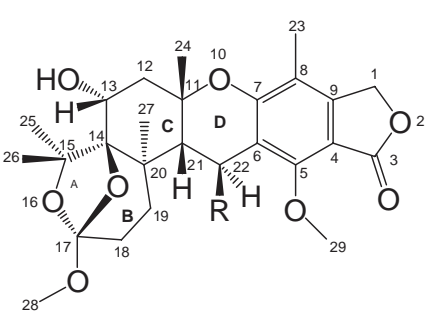

austalide $\mathrm{M}(\mathbf{1}): \mathrm{R}=\mathrm{OMe}$ austalide $N(2): R=O A C$ austalide $\mathrm{O}(\mathbf{3}): \mathrm{R}=\mathrm{OH}$

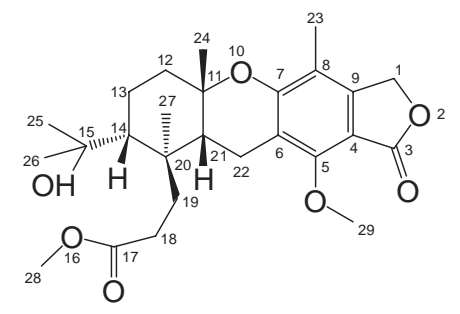

austalide $\mathrm{P}(\mathbf{4})$

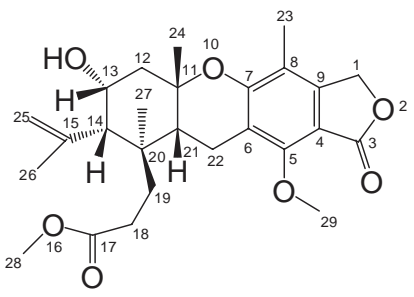

austalide Q (5)

Figure 1. Structures of austalide M-Q (1-5) isolated from Aspergillus sp.<smiles>COC1OC(=O)c2c(O)cc(O)c(C)c2[C@H]1C(C)=O</smiles>

6<smiles>Cc1c([C@@H](C)C(C)O)cc(O)c(C(=O)O)c1O</smiles>

9<smiles>CC1=C2C(=CO[C@@H](C)[C@@H]2C)C(O)=C(C(=O)O)C1=O</smiles>

12<smiles>Cc1c(O)cc(O)c2c1C(C)C(C)O2</smiles>

$\mathrm{OH}$<smiles>CC(=O)[C@H]1COC(=O)c2c(O)cc(O)c(C)c21</smiles><smiles>COC(=O)c1cc(OC)c(OC)c(OC)c1NC(=O)c1ccccc1NC(=O)c1cccnc1</smiles>

Figure 2. Known compounds (6-13) isolated from Aspergillus sp. 


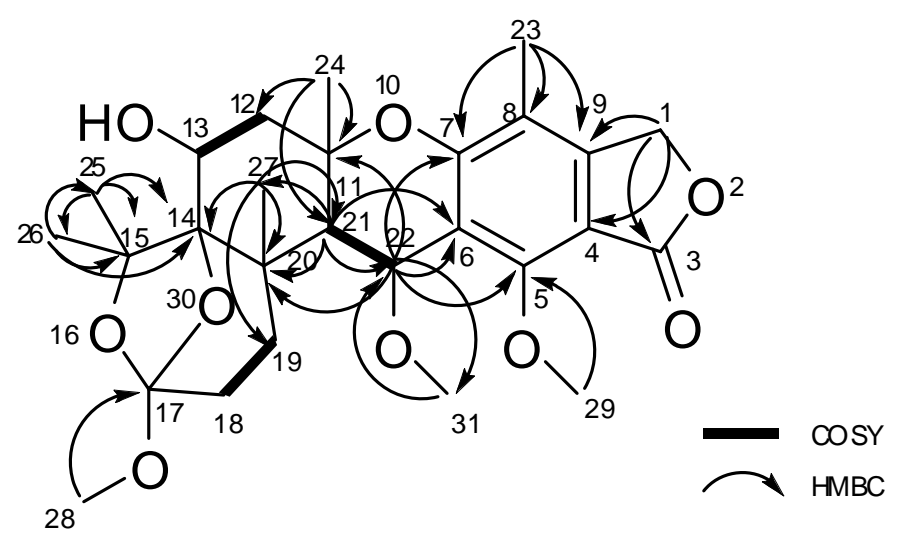

Figure 3. HMBC and ${ }^{1} \mathrm{H}-{ }^{1} \mathrm{H}$ COSY correlations of $\mathbf{1}$

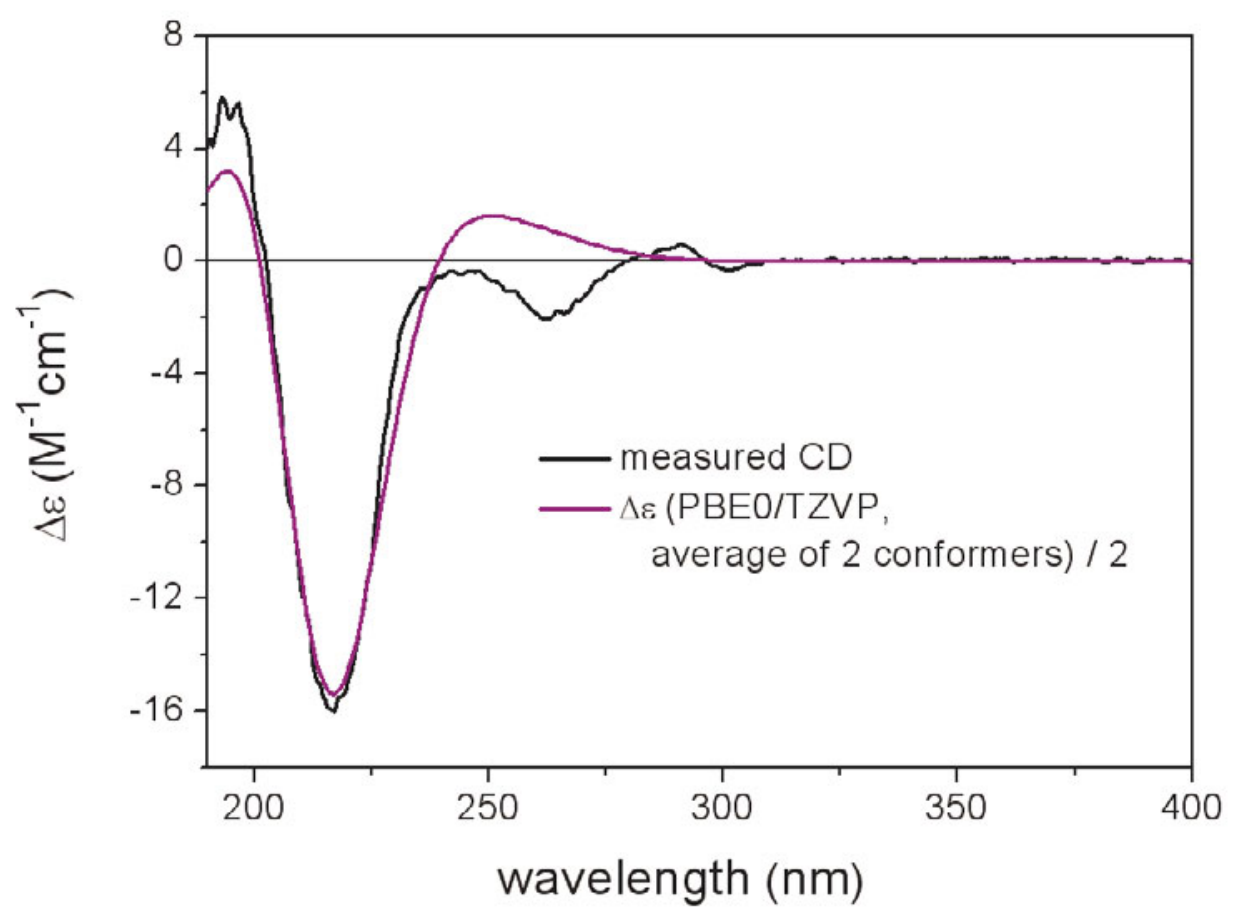

Figure 4. Experimental ECD spectrum of $\mathbf{1}$ in acetonitrile compared with the Boltzmann-weighted PBE0/TZVP spectrum calculated for the two lowest-energy conformers of the $(11 S, 13 R, 14 R, 20 R, 21 S, 22 S)$-enantiomer 

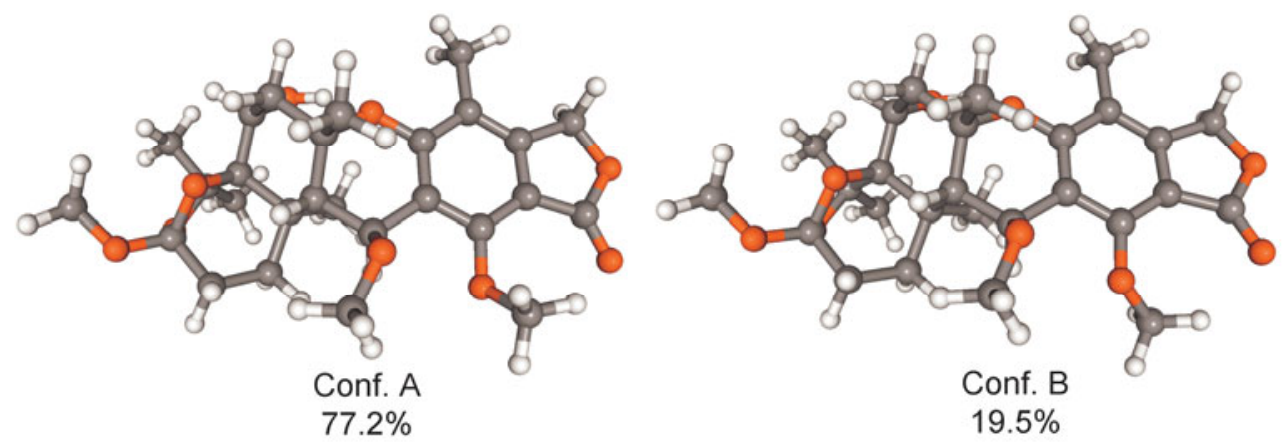

Figure 5. DFT optimized geometries of the two lowest-energy conformers of $(11 S, 13 R, 14 R, 20 R, 21 S, 22 S)-1$ with torsional angle $\omega_{\mathrm{O} 3, \mathrm{C} 3, \mathrm{C} 4, \mathrm{C} 9}-178.8^{\circ}$ and $+174.3^{\circ}$, respectively

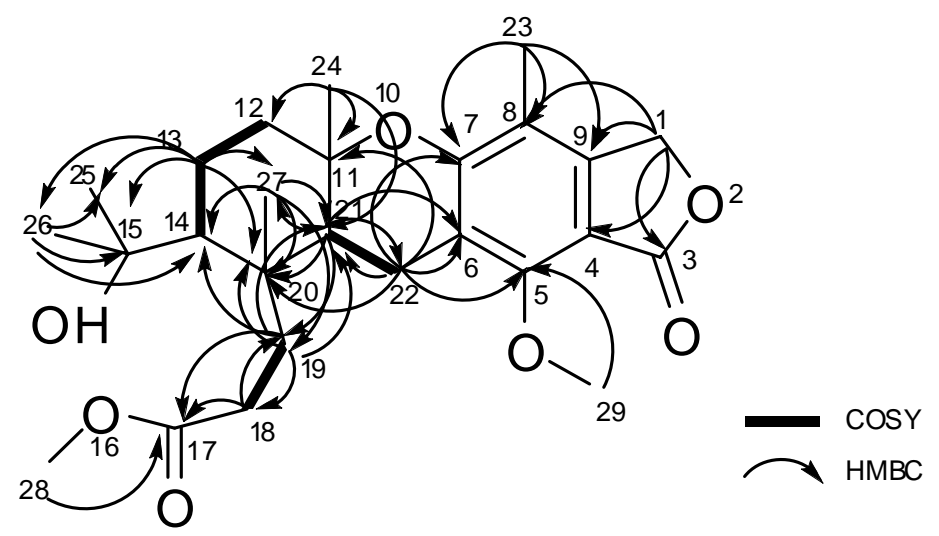

Figure 6. $\mathrm{HMBC}$ and ${ }^{1} \mathrm{H}-{ }^{1} \mathrm{H}$ COSY correlations of $\mathbf{4}$ 


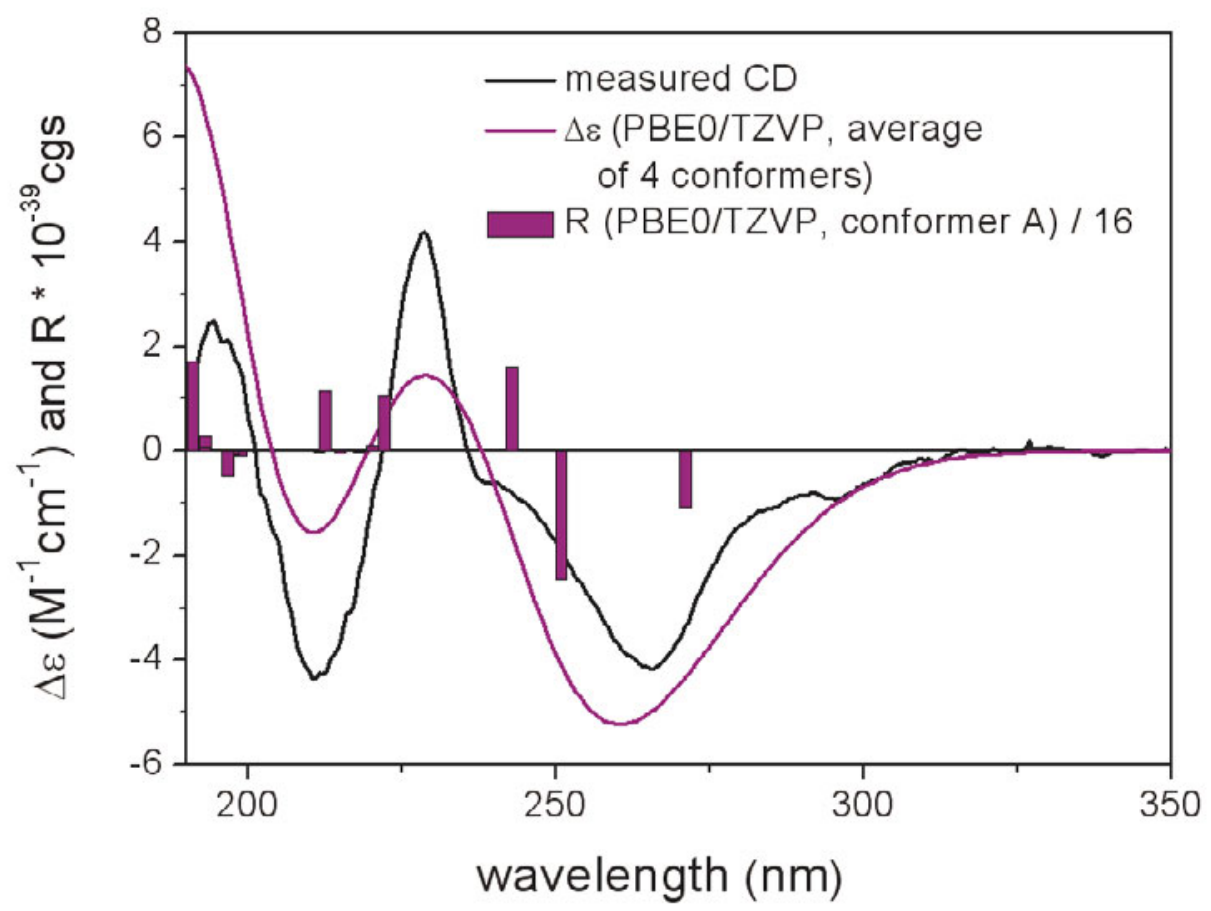

Figure 7. Experimental ECD spectrum of $\mathbf{4}$ in acetonitrile compared with the Boltzmann-weighted PBE0/TZVP spectrum calculated for the four lowest-energy conformers with $(11 S, 14 R, 20 S, 21 R)$ absolute configuration. Bars represent rotational strengths (R) of the lowest-energy conformer (40.0\%)
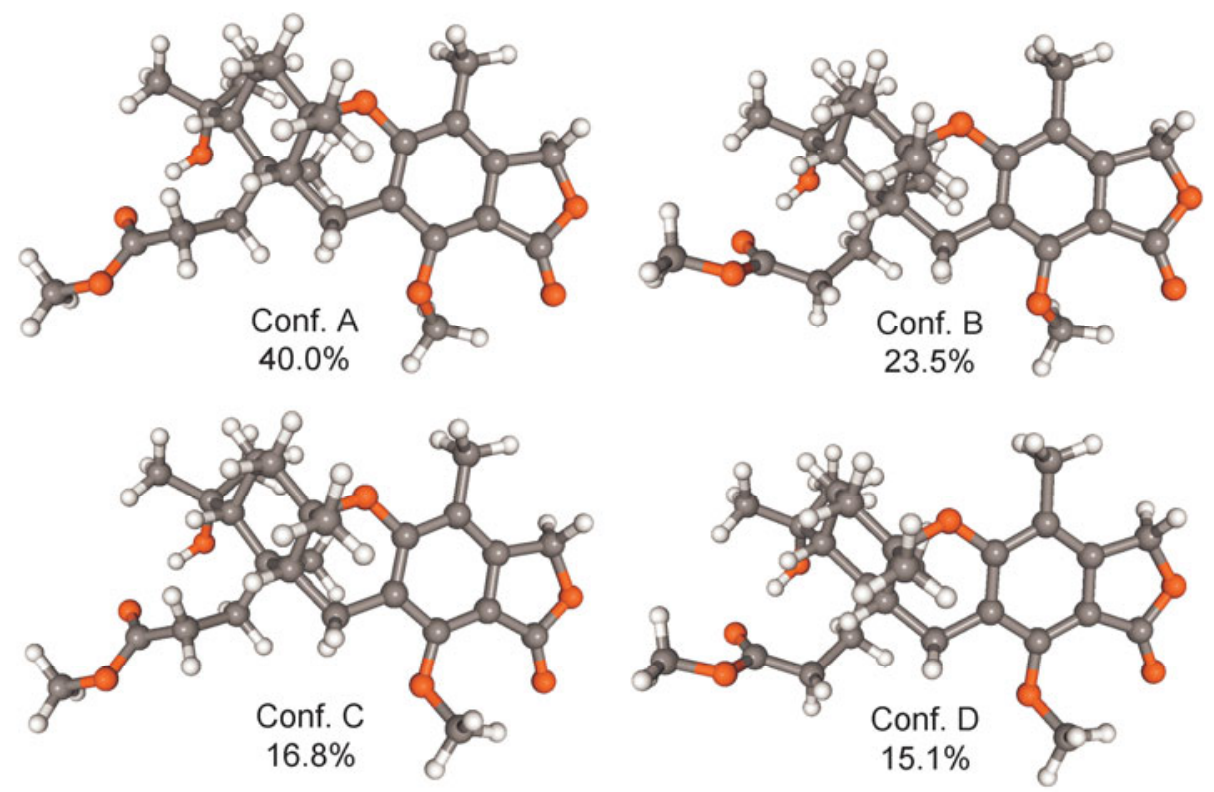

Figure 8. DFT optimized geometries and populations of the four lowest-energy conformers of $(11 S, 14 R, 20 S, 21 R)-4$ with torsional angle $\omega_{\mathrm{O} 3, \mathrm{C} 3, \mathrm{C} 4, \mathrm{C} 9}+174.61^{\circ}$, $+174.92^{\circ},-176.28^{\circ}$ and $-175.94^{\circ}$, respectively 


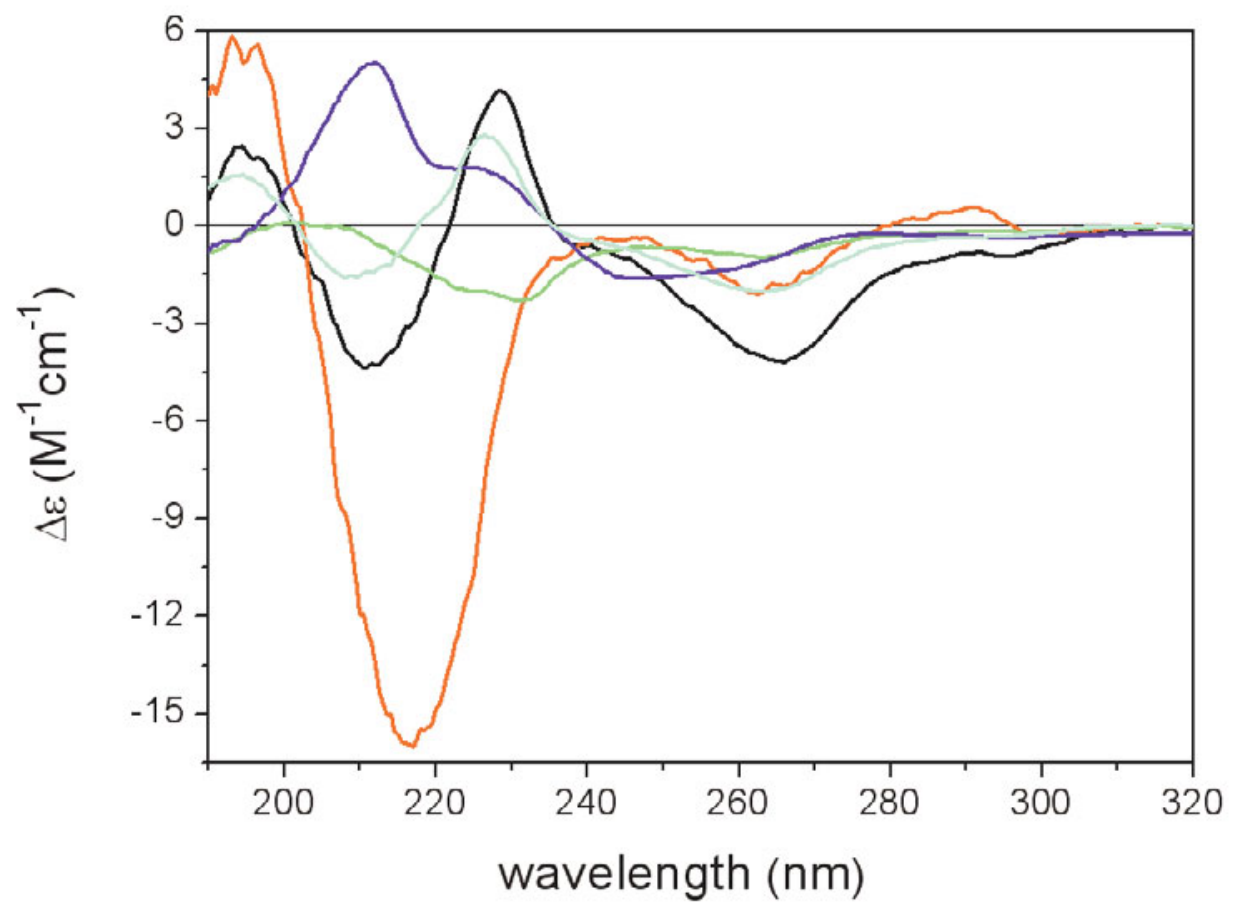

Figure 9. Experimental ECD spectra of austalide M (1, red), austalide $N$ (2, green), austalide $\mathrm{O}(\mathbf{3}$, blue $)$, austalide $\mathrm{P}(\mathbf{4}$, black) and austalide Q $(\mathbf{5}$, cyan) in acetonitrile 


\section{Supporting Information}

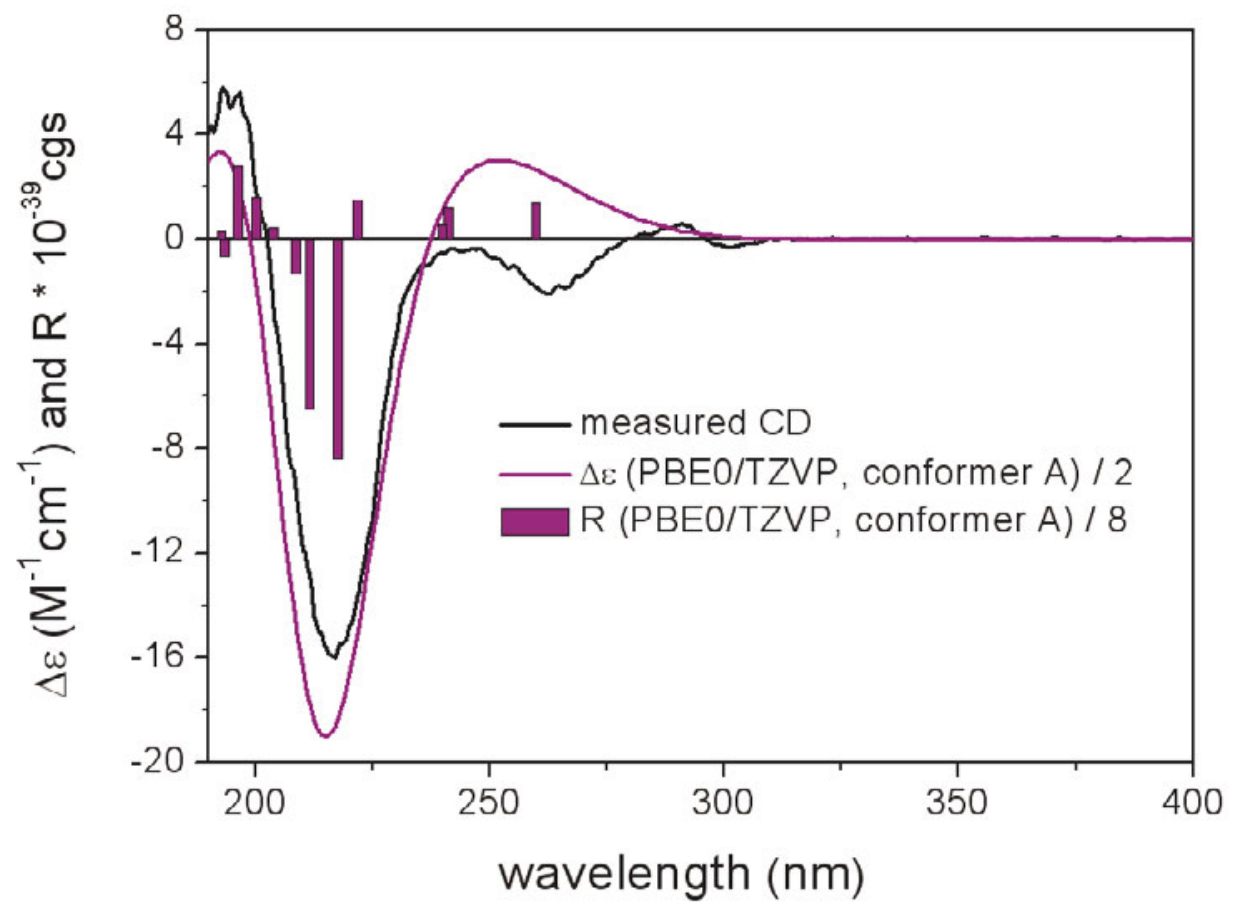

Figure SI1. Experimental ECD spectrum of 1 compared with the PBE0/TZVP spectrum of the lowest-energy $(11 S, 13 R, 14 R, 20 R, 21 S, 22 S)$-conformer (conformer A, $77.2 \%$ population). Bars represent rotational strengths $(\mathrm{R})$

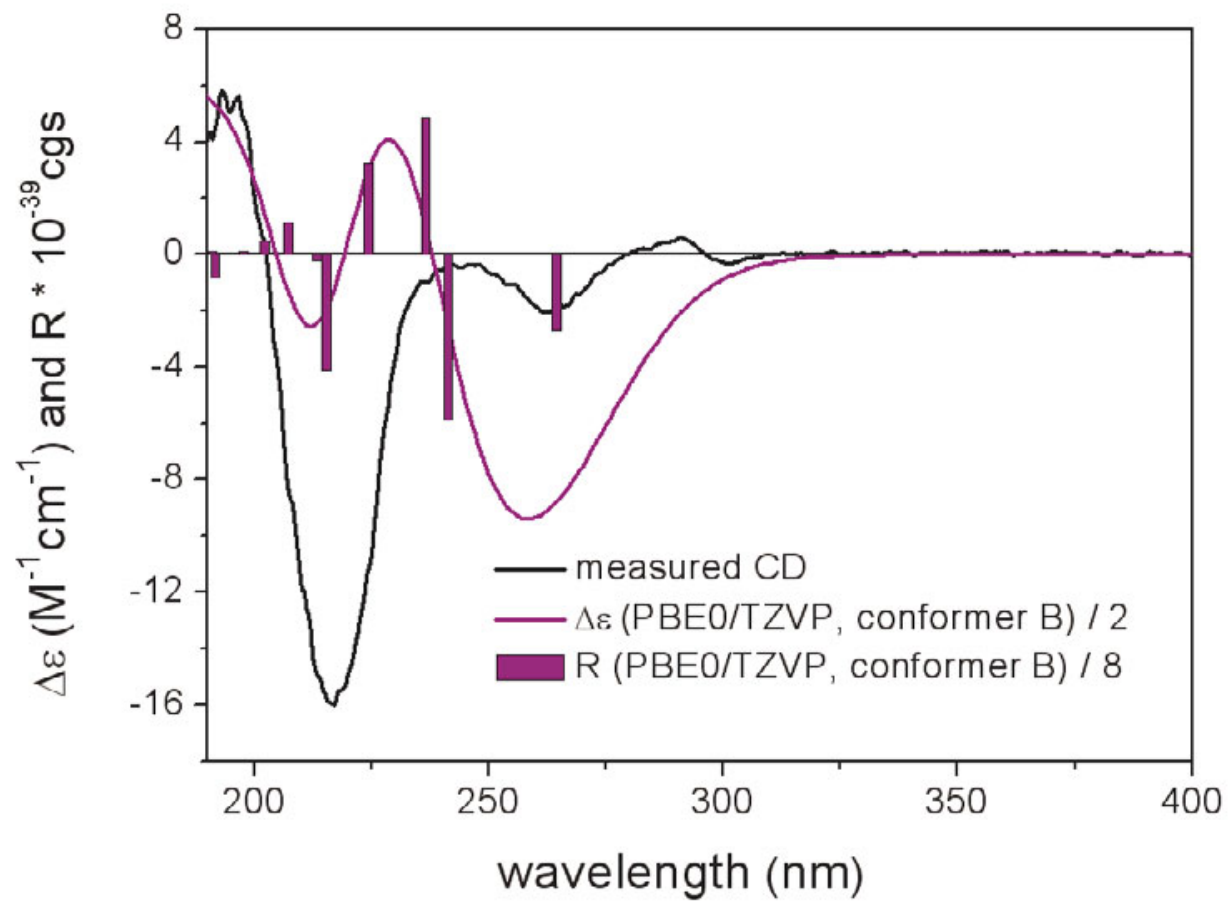

Figure SI2. Experimental ECD spectrum of 1 compared with the PBE0/TZVP spectrum of $(11 S, 13 R, 14 R, 20 R, 21 S, 22 S)$-conformer B (19.5\% population). Bars 
represent rotational strengths $(\mathrm{R})$

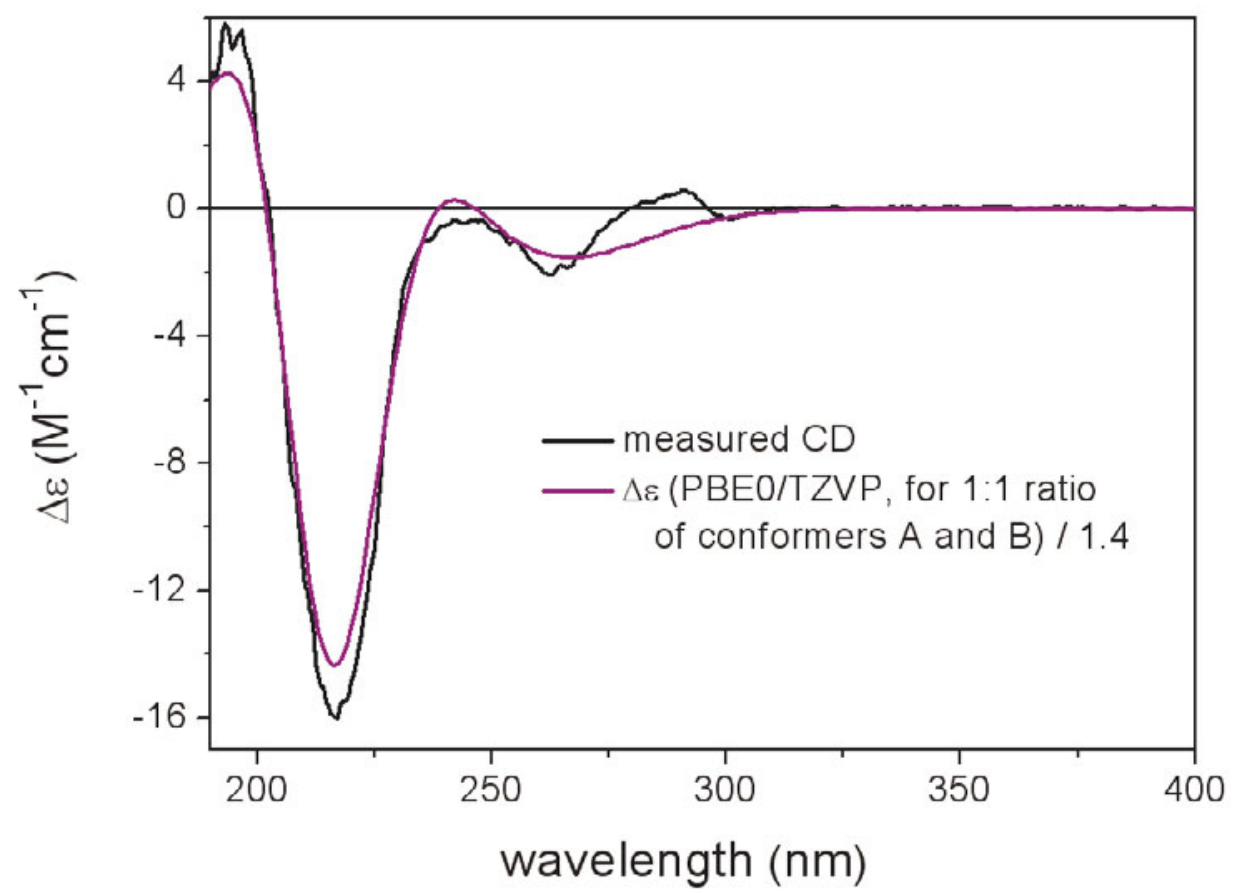

Figure SI3. Experimental ECD spectrum of 1 compared with the PBE0/TZVP spectrum of the two lowest-energy $(11 S, 13 R, 14 R, 20 R, 21 S, 22 S)$-conformers supposing their $1: 1$ ratio 